\title{
Analysis of the Employment Ability Cultivation Path of Students Major in Editing and Publishing in Local Universities
}

\author{
Wei Yu \\ Jinlin Engineering Normal University Changchun, Jilin 130052 \\ 635462679@qq.com
}

Keywords: Local universities; Editing and publishing; Employment ability

\begin{abstract}
In terms of the background that the current local universities are transforming to the universities of applied technology, students major in editing and publishing are faced with more complicated opportunities and challenges in the employment. This paper analyzes the current situation of the employment ability and urgent issues of students major in editing and publishing, and starts from the perspective of the talent training mode, curriculum, teaching staff construction and students innovative consciousness to put forward the way and method of cultivating the employment ability.
\end{abstract}

\section{Introduction}

The advance of new media technology and the development of media industrialization have changed the pattern of the information dissemination, the information dissemination way and idea of the media industry, the government and the enterprise and public institution, as well as the social need and cultivation to the dissemination talented person. The integrative development of the traditional media and the new media objectively requires that media workers shall be the inter-disciplinary talents.

In 2014, the Ministry of Education took the idea of "deepening the comprehensive reform of the educational field, and guiding the transformation of undergraduate universities to universities of applied technology" as the working focus. It is required that local universities shall profoundly explore the transformation of universities corresponding to the needs of the regional economy and the social development, and solve the problem of the traditional undergraduate education that students are lack of the practical ability. Moreover, it emphasizes to cultivate applied talents, and achieve the effective connection between the talent cultivation objective and the actual demand of society.

In such double background, the cultivation of talents major in editing and publishing faces both opportunities and challenges. Graduates of editing and publishing must carry out readjustment and repositioning of their social role, comprehensively improve the employment ability, actively adapt to the trend of the development of new media technology and mass cultural transmission diversification in the information age. Moreover, the graduates shall have the basic 
ability and innovative spirit to analyze and solve actual issues of the publishing operation and management in the new media era, and become the applied inter-disciplinary talents in the cultural creative industry such as digital publishing, network publishing, new media production and communication, as well as in the related industries to engage in the content creation and production and the cross-media publishing operation management.

\section{Employment Ability Structure of Students Major in Editing and Publishing}

Word "employment" was first put forward by the British economist Beveridge. In the 1980s, it was defined as a dynamic process of gaining initial employment, maintaining employment, as well as choosing and getting a new job after the revision by some American scholars. With the continuous development of the contemporary Chinese social economy, employment ability is also given more connotation. Usually, it is believed that the employment ability of undergraduates is the collection of multiple abilities, including learning ability, thinking ability, practical ability, social adaptive ability, etc.

Through following up the graduates major in editing and publishing as well as the interview and investigation of the industry and enterprise, it is found that in the employment ability of students major in editing and publishing, learning ability refers to the ability of acquiring knowledge; thinking ability includes the innovative ability, political identification ability, professional ethics and ideals; practical ability is the ability of using knowledge to solve problems, including professional

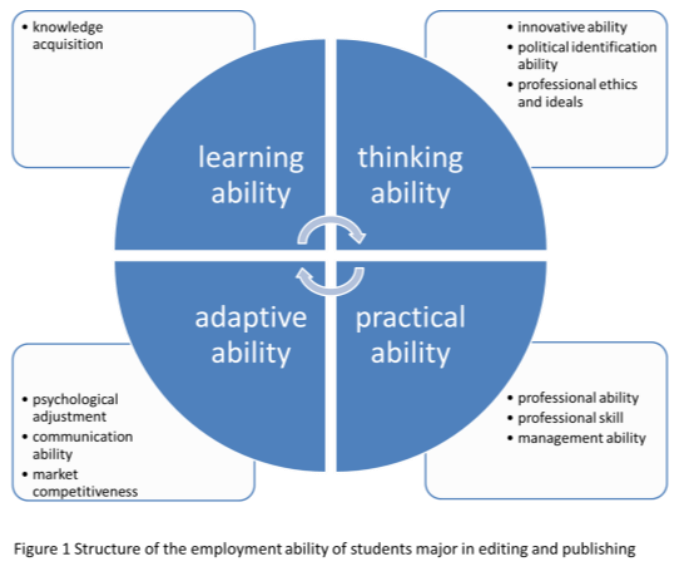

proficiency, professional skill and management ability; adaptive ability refers to the psychological adjustment ability, communication ability and the ability of actively adapting to the market. Of all the abilities mentioned above, employers pay most attention to the professional knowledge and skills with practical ability as the core. The structure is shown in Fig. 1. 


\section{Employment Ability Situation and Problem Analysis of Students Major in Editing and Publishing}

With the needs of the publishing industry and the development trend of media convergence, the university professional talent cultivation and the actual demand for talents cannot match with each other. From the perspective of ability orientation, it can be seen that students major in editing and publishing are lack of the employment ability.

Deficient in the Autonomous Learning Ability and the Innovative Consciousness. Autonomous learning ability is the premise of renewing ideas and innovating consciousness. The publishing industry enterprise belongs to the knowledge-intensive industry, and the essence is to carry out the knowledge innovation through the knowledge possession, arrangement, development and application. Therefore, the ability of creating new knowledge based on acquiring the vast knowledge and information is the essential quality of innovative editing publishers.

In the context of the media convergence, editing and publishing major pays more attention to the knowledge and ability of the professional technical crossing field, interdisciplinary field and human science field. Therefore, students major in editing and publishing cannot meet the needs of the industry simply with a certain professional knowledge. Instead, they shall constantly make every effort to re-learn, re-think and re-improve. Students shall expand the range of knowledge through the self-regulated learning, and explore the depth of knowledge through innovative thinking, so as to become the "eclectics" and "all-round person" to actively adapt to the interdisciplinary and cross-subject editing and publishing work in the media convergence age.

Social Adaptive Ability Is not Strong. Social adaptive ability is the essential ability of students major in editing and publishing when they get involved in the job market, which mainly embodies in the ability to actively adjust psychological state, positively communicate, as well as understand the publishing market operation and competitive social activities. These abilities are also the primary standard of employers selecting talents, as well as the important factor to decide the work achievements and future development of graduates.

Usually, students major in editing and publishing believe that editing work mainly deals with texts. In the process of learning, they pay more attention to the text editing ability, so that their market strategy consciousness, information transformation ability and communication ability are comparatively weak. At present, students are all the only child after 1990s who grow up after the reform and opening. They have strong personality and multiple values, while they are lack of the teamwork awareness with weak communication and coordination ability. Even some students have barriers in personal communication to some degree. They would like to be alone in the interpersonal communication, and it is difficult for them to deal well with the complex problems in the practical work. This requires that students major in editing and publishing shall not only have the basic knowledge of philosophy, social science, humanities, management science, natural 
science and technology science, but meanwhile the strong organizational coordination ability, communication ability and interpersonal ability.

Professional Practical Ability is not Solid Enough. Practical ability is the main ability that makes students major in editing and publishing different from college students in other majors, and it is also the core competitiveness of students major in editing and publishing. On the whole, the professional practical ability of students major in editing and publishing is not solid enough, which mainly embodies in the editing technique, publishing technique, issuing technique and a series of professional abilities, and the understanding of the major is not profound enough. In the aspect of academic and professional skills, many students major in editing and publishing are not good at mastering professional knowledge. Moreover, their scope of knowledge is not wide enough, and the academic foundation is not solid. Only one has a profound professional background can he master the development movement and trend of the subject, and predict and cultivate the market in the discipline field. The publishing practice proves that only those graduates with profound discipline background can have the potential of ascending development, who can better adapt to the requirement of modern editing and publishing major.

\section{Ways of Improving Employment Ability of Students Major in Editing and Publishing}

Establishing the Talent Cultivation Mode of Collaborative Innovation between "6+1" Universities and Enterprises. The so-called " $6+1$ " means universities will cooperate with the "newspaper office, publication office, publishing house, website, printing house and bookstore" to make talent cultivation program, research and develop comprehensive teaching research projects, guide the graduation thesis and design of students, guide students to participate in the professional qualification appraisal, and manage and evaluate the internship results of the students.

Optimizing the Design of the "Ability-oriented" Curriculum System. Establishing professional education and teaching instruction committee to carry out the one-by-one analysis, induction and summary of the core ability of publishing media talents, and set up the curriculum system of the "platform + module". Constructing the curriculum system of "three platforms + two modules", which respectively refer to the platforms of liberal education, discipline education and professional education, as well as the modules of media editing and media operation. To avoid the disconnection between the curriculum and the industry needs, it is available to regularly employ the industry elites to teach one to three courses, or develop academic lectures and jointly compile textbooks.

Universities and Enterprises Jointly Construct the on-campus and off-campus Production-Teaching Base Cluster to Form the "Quadruple-Double" Mechanism. Based on the on-campus experimental center, the off-campus practice teaching base and the college students' innovation and entrepreneurship studio to set up the on-campus and off-campus 
production-teaching base cluster of "internal and external coordination, university and enterprise cooperation and the cross connection between simulation and practice", and form the "quadruple-double" mechanism of "double posts, double teachers, double identities and double results" of "the close relationship between classrooms and posts, teachers and tutors, students and employees, and assignments and works".

Improving the Applied Talents Evaluation Mechanism of the Profound Integration Between Universities And Enterprises. It is mainly implemented from two aspects. The first is establishing the learning evaluation mechanism of the profound integration between universities and enterprises. Full-time teachers and industry experts can evaluate the students' learning and practical ability based on the needs of the post. The second is insisting on the occupational qualification access mechanism. It introduces the vocational qualification standard, and evaluates the students' professional practical ability and level through carrying out the vocational qualification certificate examination.

Improving the "Double Teachers and Double Abilities" of Professional Teachers. Poor faculty of editing and publishing is the weakness of many universities. Usually, full-time teachers have high academic qualifications and strong research ability, while most of them are lack of the industry experiences and skills. The employed teachers are rich in experience, while they can spend limited time in the teaching. Based on the situation, universities shall actively run the school with enterprises together, give full play to the practice guidance function of the industry teachers, and strengthen the vocational training of professional teachers. In this way, it can not only understand the industry needs in a close distance to carry out the cultivation according to needs, but cultivate talents needed by the industry jointly with the assistance of editors, managers and market staffs who are rich in experience.

Improving the Psychological Quality and Forming Good Habits of the Character. Similarly, psychological quality and character habit also influence the employment of students. How to practice a good psychological quality and character habit is also crucially important. In today's society, one with a high IQ doesn't mean that he will have a good employment environment, since EQ is as important as IQ. Even EQ can have more influence on the future of students than IQ. Therefore, one shall pay attention to the manners and the way of doing things during the academic year, focus on cultivating the honest and optimistic attitude, and form the independent and autonomous habits. These excellent qualities will definitely be crucially important to one's development in the future.

\section{Conclusion}

Local universities shall combine their own advantages and the actual discipline construction to carry out dynamic adjustment and structure optimization of the editing and publishing major. More importantly, they shall pay attention to have the profound connection with the industry, better apply the "Internet thinking" to the 
discipline construction, strengthen the needs of users, take the vocational ability as the orientation, and actively adapt to the development of local economy and society, thus realizing the "triple win" of the school, the employer and the student.

\section{References}

[1] K. Yan, the Employment Problems of Graduates Major in Editing and Publishing, Master of Journalistic University, 5, (2010)97-98. (In Chinese)

[2] X. C. Zhu, On the Employment Ability Cultivation of Undergraduates, Higher Education Exploration, 4(2009)124-127.(In Chinese)

[3] J. W. Li, A Study on the Education Situation of Postgraduates Major in Editing and Publishing in China, Journal of Henan University(Social Science Edition), 3(2007)167-173.(In Chinese)

[4] H. Y. Li, A Study on the Cultivation Mode of Talents Major in Editing and Publishing in Universities, Journal of Guangxi Normal University: Philosophy and Social Science Edition, 6(2011)132-135.(In Chinese)

[5] W. J. Zhang, Analysis of Entrepreneurship and Employment Path of Undergraduates Major in Editing and Publishing, Journal of SUEE, 4(2016)96-98. (In Chinese)

[6] W. S. Qi, What is the Way of Editing and Publishing of Universities, 3(2009). 20-22(In Chinese)

[7] Z. H. Qiao, Employment Ability Structure of Undergraduates and the Influence on Employment Results, Psychological Development and Education, 3(2011)274-281. (In Chinese)

[8] J. K. Li, A Study on Employment Ability Structure of Undergraduates and Influencing Factors , Chinese Youth Studies, 11(2012)89-92.(In Chinese)

[9] L.J.Jia, a Study on Employment Ability Structure of Undergraduates. Education Development Research, 13-14(2013)51-56.(In Chinese)

[10]J. Zhou, Current Situation Analysis and Countermeasures of the Employment Ability of Undergraduates, Heilongjiang Education (University Research and Evaluation), 3(2010)22-24. (In Chinese)

[11]X. Jin, Empirical Study on the Employment Ability Structure and Current Situation of Contemporary Undergraduates, Journal of Northeast Normal University (PHILOSOPHY AND SOCIAL SCIENCES),9(2012)237-240.(In Chinese) 